\title{
Metrological support of inverse problems in nonlinear inertial systems
}

\author{
O.V. Poliarus, Ya.S. Brovko, Ye.O. Poliakov, S.D. Yanushkevych \\ Kharkiv National Automobile and Highway University, Yaroslava Mudrogo Str., 25, 61002, Kharkiv, Ukraine \\ poliarus.kharkov@ukr.net
}

\begin{abstract}
It is shown that there is a medium in a measuring channel between the object and the measuring device, which in practice can be nonlinear and inertial. An example of such a medium is a pipe filled with gas or a liquid with air bubbles inside. It is noted that the characteristics of the channel output signals can differ significantly from the characteristics of the input signals. A method for solving the inverse measurement problem based on using the Hammerstein model, which consists of two consecutive virtual blocks, is proposed. The order of solving the inverse measurement problem is established: first the problem is solved for a linear inertial block and then for a nonlinear non-inertial one. It is found that the accuracy of input signals restoration depends essentially on matching the pass band of the inertial block with the width of the signal spectrum at the output of the nonlinear inertial block. The requirements are developed to input signals, the measurement function, the bandwidth of the channel, the noise level in it, the accuracy of the output signal measurement, under which the necessary quality of the metrological support is achieved for the inverse measurement problem.
\end{abstract}

Keywords: measuring channel, inverse measurement problem, metrological support, nonlinear inertial system.

\section{Introduction}

Each measurement system, measuring channel or sensor contains a measuring medium between the measurement object and the measuring transducer and also a signal processing device. This medium is called a measuring line (ML). It can be long as, for example, ML between the technical object and the pressure sensor or an area essential for the radio waves propagation in telemetry and radio detection and ranging, or very short, for example, in microaccelerometers, microgyroscopes, etc. In measurement systems, pipes filled with liquid or gas can be used to transfer pressure from a technical object to a sensor. During maintenance of a measuring channel (MC) air can penetrate into the liquid and then the channel turns into a nonlinear inertial one, that is, it becomes a nonlinear system with memory [1]. These MCs are widely used in practice, for example, in remote sensing systems [2], active safety systems of cars, computer vision systems, devices for estimation of camera position and orientation that uses information from inertial sensors [3]. The input action (e. g., pressure) characteristics measured at the sensor output can differ significantly from the actual ones, that is, measurements in some cases are not reliable. Hence, the task of determining the characteristics of action (signal) at the input of the ML is an important inverse measurement problem.

\section{Analysis of recent research and publications}

For accurate measurements with little uncertainty, it is necessary to have adequate mathematical models of MC and, if possible, a complete information about input random processes that are measured. The general structure of such models is given, for example, in $[4,5]$. The inverse problem is solved exactly if the mathematical model of a linear inertial $\mathrm{MC}$ in the form of a convolution integral is completely known $[6,7]$. In real conditions, noises and errors of the output signal measurement are present in MC. This led to the fact that only approximate methods of inverse problems solving can be used in practice. In [8], the measured output signal (realization of a random process) is compared in a functional space with a theoretical unknown output signal, which is represented as a Karhunen-Loève series. The difference between them is minimized and thus unknown coefficients of the series are obtained, that is, the restoration of the signal to the MC input is carried out. The general approach to solving inverse measurement problem for a nonlinear inertial channel is given in $[9,10]$. However, 


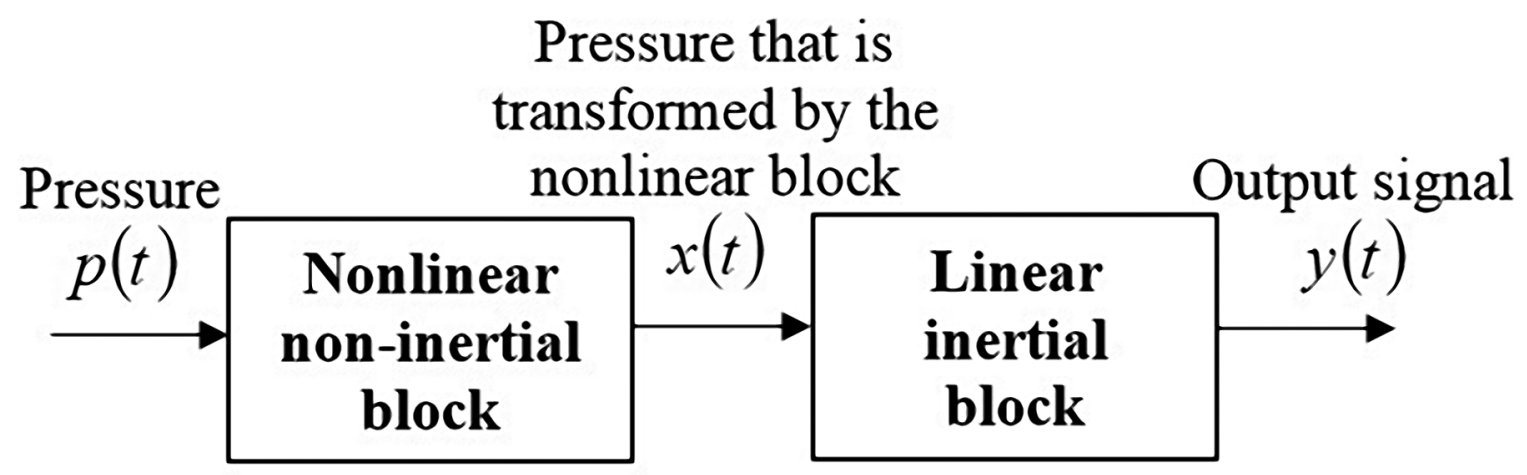

Fig. 1. Model of pressure measuring channel

up to now, the requirements for metrological support of inverse measurement problem in nonlinear inertial MCs are not outlined.

The purpose of the article is development of proposals for metrological support of inverse measurement problems in nonlinear inertial measuring channels and evaluation of conditions.

\section{Modern approaches to the analysis of nonlinear inertial measuring channels}

In general case, the nonlinear inertial MCs analysis is accompanied by considerable difficulties. Many researchers try to linearize the channel measurement function or eliminate the conditions for appearance of its nonlinearity. The most universal method for modeling such channels is based on the Volterra's series model [11], which has been proposed long ago, but so far it is not widely used in practice due to complexity and cumbersomeness of the mathematical apparatus, although it can be applied even in the presence of noise and non-stationary input signals in MCs [12]. Now, the most suitable models of MC are block-oriented models [13], in which the physical properties of nonlinearity and inertiality are divided into different blocks. These models include, in particular, the Hammerstein model [14], consisting of sequentially connected nonlinear non-inertial and linear inertial blocks. Such a model has created possibilities for an approximate solution of inverse measurement problem in a nonlinear inertial MC.

\section{Physical bases for solving the inverse measurement problem}

In the Hammerstein model (Fig. 1), an input signal (for example, pressure) $p(t)$ passes sequentially through two virtual blocks and is measured at the output of the linear inertial block. The measured output signal $y_{m}(t)$ is compared with unknown theoretical signal $y(t)$. This signal is connected with the signal by the convolution equation, which is typical for linear inertial systems. In accordance with the method presented in [8], the inverse problem is solved and the signal $x(t)$ is evaluated. Thus, we have a nonlinear non-inertial block with a known signal at its output. For receiving an input signal $p(t)$ it is necessary to have information about the measurement function of the nonlinear block, for example, to use the test input signals and to solve the problem of the nonlinear model identification. In the article, the measurement function of this block is assumed to be given as a polynomial (1)

$x(t)=a_{0}+a_{1} p(t)+a_{2} p^{2}(t)+\ldots+a_{\mathrm{n}-1} p^{\mathrm{n}-1}(t)$.

where $a_{i}, i=1, . ., n-$ the dimensional coefficients of the measurement function which are known in this article.

Let's expand the already known function $x(t)$, as well as the unknown realization $p(t)$ of the input random signal in the Karhunen-Loève series

$$
\begin{gathered}
x(t)=\sum_{\mathrm{i}=0}^{\mathrm{n}-1} \gamma_{\mathrm{i}} \psi_{\mathrm{i}}(t), \\
p(t)=\sum_{\mathrm{k}=0}^{\mathrm{m}-1} \beta_{\mathrm{k}} \psi_{\mathrm{k}}(t),
\end{gathered}
$$

where $\psi_{\mathrm{i}}(t), \psi_{\mathrm{k}}(t)$ - chosen by a researcher the same orthogonal functions of time, $\gamma_{i}-$ known coefficients, and $\beta_{\mathrm{k}}-$ unknown random coefficients.

The number of coefficients $\gamma_{i}$ and $\beta_{\mathrm{k}}$ depends on the shape of functions $x(t), p(t)$ and should be the same, that is, $m=n$. Let's substitute the relations (2) and (3) into formula (1) and, in particular case, at $n=2$ one can obtain

$$
\sum_{\mathrm{i}=0}^{\mathrm{n}-1} \gamma_{\mathrm{i}} \psi_{\mathrm{i}}(t)=a_{0}+a_{1} \cdot \sum_{\mathrm{i}=0}^{\mathrm{n}-1} \beta_{\mathrm{i}} \psi_{\mathrm{i}}(t)+a_{2} \cdot\left(\sum_{\mathrm{i}=0}^{\mathrm{n}-1} \beta_{\mathrm{i}} \psi_{\mathrm{i}}(t)\right)^{2} \text {. }
$$

To simplify the expression (4), its integration on the interval of observation $[0, T]$ is carried out and the orthogonality of functions $\psi_{\mathrm{i}}(t)$ and $\psi_{\mathrm{k}}(t)$ is taken into account. The left-hand side of equation (4) is completely known. Then the problem of determining the coefficients $\beta_{\mathrm{k}}$ is reduced to minimizing the objective function of many variables, that is, the difference between the left and right sides of the equation (4). Minimization is carried out by using the algorithm of global random search (genetic algorithm). As a result, all coefficients (4) and, therefore, the realization of random input signal (3) are determined.

From the physical point of view, there are limitations on the solution of the inverse measurement 
problem. They are caused by relation between the spectrum width $\Delta f_{\mathrm{x}}$ of the virtual signal $x(t)$ and the bandwidth of the linear inertial block $\Delta f$. If $\Delta f_{\mathrm{x}}>\Delta f$, then there is a loss of measurement information, which, of course, increases the errors of the input signal restoration. The spectrum width $\Delta f_{\mathrm{x}}$ depends on the shape of realization $p(t)$, the noise power and degree of the polynomial (1). To evaluate the influence of various factors on the results of the inverse problem solution, let's carry out the mathematical modeling.

\section{Results of the mathematical modeling}

Let's consider several variants of an input signal: a) a harmonic signal; b) superposition of several harmonic signals; c) the above signals together with the white Gaussian noise of different powers. The time constants of the linear inertial block $\tau_{0} \approx(\Delta f)^{-1}$ were: $0.05 \mathrm{~s}, 0.1 \mathrm{~s}, 0.3 \mathrm{~s}, 0.5 \mathrm{~s}$. Since the mathematical model of MC is considered to be known, it is always possible to calculate the output signal of MC, which is an analog of the measured output signal. After solving the inverse problem, the calculated input signal is compared with the realization of random input signal that was given in modeling as analog of the reference input signal, i. e., the totality of reference quantity values. This provides the basis for determining the errors of the input signal restoration.

Fig. 2 shows the restoration result (dashed line) of the input signal (pressure) as a sum of two harmonics (solid line) for polinomial measurement function of the nonlinear block (the degree of a polynomial is equal to two) and the time constant of the inertial block equal to $0.5 \mathrm{~s}$. Despite the large time constant of the inertial block, the restored signal almost completely repeats the shape of the input signal. This is due to the fact that the main harmonics of the input signal after the nonlinear transformation were within the pass band of the inertial block. On the contrary, if this obvious condition for the experimental signal is violated (Fig. 3), the quality of the input signal shape restoration deteriorates.

The results of mathematical modeling show:

- the relative errors of input signal restoration usually increase (and not monotonically) when the duration of the signal becomes larger; non-monotonic change is due to the features of the genetic algorithm work;

- input and output white noise are not restored in inverse problem, but with an increase of the noise power the restoration errors also rise;

- the greater measurement errors of the output signal in MC, the more significant are the restoration errors of the input signal;

- accuracy of the input signal restoration depends essentially on the matching of the signal spectrum, which is transformed by a nonlinear block, and the bandwidth of the inertial block;

- the measurement function of a nonlinear block should be known, although it is difficult to implement in practice; from the fundamental point of view, the solution of the inverse problem is possible even with a poorly known function but the solution is not always reliable.

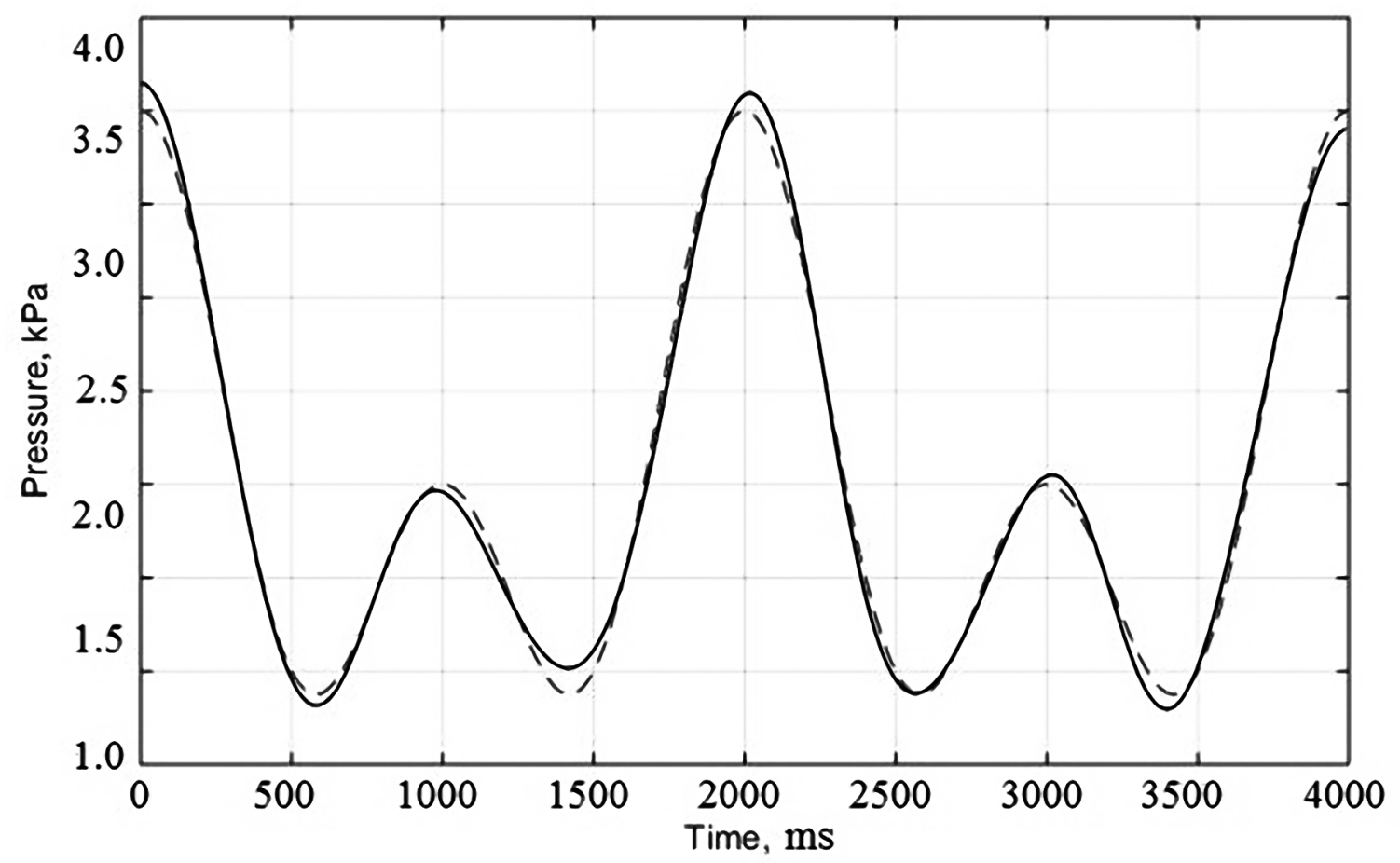

Fig. 2. The result of the input signal restoration: solid line - the realization of random input signal and dashed line recovered signal 


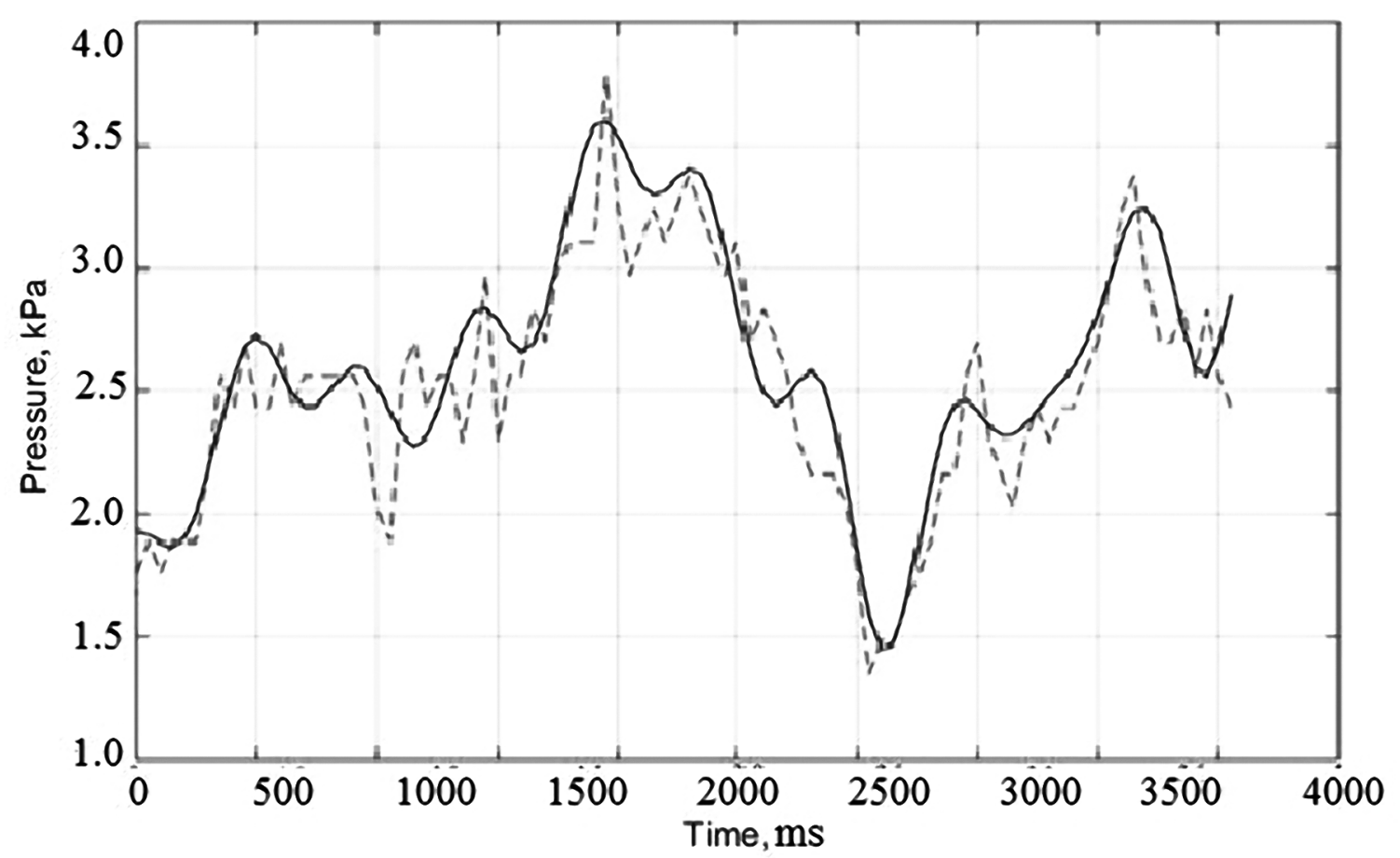

Fig. 3. The result of the input signal restoration: solid line - the realization of experimental signal and dashed line recovered signal

The main proposals for metrological support of inverse measurement problems

The article does not consider the usual tasks of metrological support, which are common for metrology. The main issue is the study of conditions under which the solution of the inverse measurement problem satisfies the specified requirements for accuracy of signal restoration in a nonlinear inertial channel. The proposals for metrological support of the inverse problem are based on the results of modeling but do not contain specific figures, since these figures can differ significantly for different measuring channels. The main task is to create a mathematical model of a nonlinear inertial channel taking into account the virtuality of the two blocks that have been previously described. For example, the measurement function of non-linear block can be obtained if the pass band of the linear inertial block is wide. The time constant of this block can be measured if there are restrictions on the nonlinearity of the non-inertial block. In general case, it is possible to carry out theoretical studies to create the desired model with subsequent its verification for particular cases. A reliable model does not guarantee reliable results if the accuracy of the output signal measurement is insufficient or the noise level in the measuring channel is high. No suggestions will help solve the inverse problem of measurements if width of the signal spectrum at the output of the nonlinear block is much more greater than the bandwidth of the inertial block. In general, the proposals for metrological support can be formulated only for a specific nonlinear inertial channel which operates under certain conditions.

\section{Conclusions}

The main conclusion of the paper is that the inverse measurement problem for a nonlinear inertial channel can be solved in many particular cases. The reliable solution of such a problem in general case is impossible. Therefore, before solving the inverse measurement problem, it is necessary to make sure that the conditions for its solving exist. The application of the proposed method for solving the inverse problem is expediently if it is impossible to get rid of the nonlinearity of the channel. The main requirements that provide the solution of the inverse measurement problem is the creation of a reliable mathematical model of the nonlinear inertial channel, measuring the output signal with a required accuracy and minimizing the noise level in the channel. 


\title{
Метрологічне забезпечення обернених вимірювальних задач в нелінійних інерційних системах
}

\author{
О.В. Полярус, Я.С. Бровко, Є.О. Поляков, С.Д. Янушкевич \\ Харківський національний автомобільно-дорожній університет, вул. Ярослава Мудрого, 25, 61002, Харків, Україна
} poliarus.kharkov@ukr.net

\section{Анотація}

Показано, що у вимірювальному каналі між об’єктом та вимірювальним пристроєм існує середовище, яке на практиці може бути нелінійним та інерційним. Прикладом такого середовища є труба, що заповнена повітрям або рідиною з повітряними бульбашками всередині. Відзначено, що характеристики вихідних сигналів каналу можуть істотно відрізнятися від характеристик вхідних. Запропоновано метод розв'язання оберненої задачі вимірювань на основі використання моделі Гаммерштейна, що складається з двох послідовних віртуальних блоків. Встановлено порядок розв’язання оберненої задачі вимірювань: спочатку задача розв’язується для лінійного інерційного блоку, а потім для нелінійного неінерційного. Виявлено, що точність відновлення вхідних сигналів істотно залежить від узгодження смуги пропускання інерційного блоку з шириною спектру сигналу на виході нелінійного неінерційного блоку.

Розроблено вимоги до вхідних сигналів, функції перетворення, смуги пропускання каналу, рівня шумів у ньому, точності вимірювання вихідного сигналу, при яких забезпечується необхідна якість метрологічного забезпечення оберненої задачі вимірювань.

Ключові слова: вимірювальний канал, обернена задача вимірювань, метрологічне забезпечення, нелінійна інерційна система.

\section{Метрологическое обеспечение обратных измерительных задач в нелинейных инерционных системах}

\author{
А.В. Полярус, Я.С. Бровко, Е.А. Поляков, С.Д. Янушкевич \\ Харьковский национальный автомобильно-дорожный университет, ул. Ярослава Мудрого, 25, 61002, Харьков, Украина \\ poliarus.kharkov@ukr.net
}

\section{Аннотация}

Показано, что в измерительном канале между объектом и измерительным устройством существует среда, которая на практике может бать нелинейной и инерционной. Примером такой среды является труба, заполненная воздухом или жидкостью с воздушными пузырьками внутри. Отмечено, что характеристики входных сигналов канала могут существенно отличаться от характеристик входных. Предложен метод решения обратной задачи измерений на основе использования модели Гаммерштейна, которая состоит из двух последовательных виртуальных блоков. Установлен порядок решения обратной задачи измерений: сначала задача решается для линейного инерционного блока, а потом для нелинейного неинерционного. Обнаружено, что точность восстановления входных сигналов существенно зависит от согласования полосы пропускання инерционного блока с шириной спектра сигнала на выходе нелинейного инерционного блока.

Разработаны требования к входным сигналам, функции преобразования, полосе пропускання канала, уровня шумов в нем, точности измерения выходного сигнала, при которых достигается необходимое качество метрологического обеспечения обратной задачи измерений.

Ключевые слова: измерительный канал, обратная задача измерений, метрологическое обеспечение, нелинейная инерционная система. 


\section{References}

1. Hashemian H. M. Monitoring and Measuring I\&C Performance in Nuclear Power Plants. International Society of Automation, 2014. 362 p.

2. Pavlenko V.D., Speranskyy V.A. Analysis of identification accuracy of nonlinear system based on Volterra model in frequency domain. American Journal of Modeling and Optimization, 2013, vol. 1, no. 2, pp. 11-18.

3. Schön Thomas B. Estimation of Nonlinear Dynamic Systems. Theory and Applications. Department of Electrical Engineering Linköpings universitet, Linköping, Sweden, 2006. 284 p.

4. Abdu Idris Omer, Taleb M.M. Measurement systems: characteristics and models. Europian Scientific Journal, 2014, vol. 10, no. 9, pp. 248260.

5. Ernest O. Doebelin. Measurement systems. Application and design. McGraw-Hill Publishing Company, 1990. 960 p.

6. Solopchenko G. N. Obratnyie zadachi v izmeritelnyih protsedurah [Inverse problems in measuring procedures]. Izmerenie, kontrol, avtomatizatsiya, 1983, no. 2(46), pp. 32-46 (in Russian).

7. Tihonov A. N., Arsenin V. Ya. Metodyi resheniya nekorrektnyih zadach [Methods for solving illposed problems]. Moscow, Nauka, 1979. 288 p.

8. Poliarus O.V., Poliakov Ye.O. Nablyzhene rozviazannia obernenoi zadachi vymiriuvan ta yoho metrolohichne zabezpechennia [Approximate solution of the inverse problem of measurements and its metrological support]. Monohrafiia. Kharkov, Lider, 2014. 120 p. (in Ukrainian).

9. Poliarus O.V., Brovko Ya.S. Kompleksnyi pidkhid do analizu vymiriuvalnoho kanalu tysku. [Comprehensive approach to the analysis of the measuring pressure channel]. Tekhnolohyia pryborostroenyia, 2016, no. 2, pp. 54-57 (in Ukrainian).

10. Poliarus O.V., Brovko Ja.S., Poliakov E. O., Ianushkevich S. D. The application restrictions of the nonlinear inertial measurement systems models in the inverse problems solution. VI International Scientific and Technical Conference. Metrology. Information measuring technologies and systems, 24-25 October 2017, Kharkov, pp. 117-118.

11. Flake R.H. Volterra series representation of nonlinear systems. IEEE Transactions on Applied Superconductivity, 1963, vol. 81, no. 1, pp. 330335.

12. Bendat Julius S. Spectral Techniques for Nonlinear System Analysis and Identification. Shock and Vibration, 1993, vol. 1, no. 1, pp. 21-31. John Wiley \& Sons Inc.

13. Unbehauen Heinz, Ley Frank. Das Ingenieurwissen Regelungs und Steuerungstechnik. Springer Vieweg, 2014. 123 p.

14. Brouri A., Giri F., Mkhida A., Chhibat F.Z. Identification of Nonlinear Systems Structured by Hammerstein-Wiener Model. International Journal of Electrical, Computer, Energetic, Electronic and Communication Engineering, 2014, vol. 8, no. 5, pp. 738-741. 